\title{
Editorial
}

\section{Mendudukan Kembali Judicial Activism dan Judicial Restraint dalam Kerangka Demokrasi}

DOI: https://doi.org/10.22304/pjih.v4n3.a0

Judicial activism dan judicial restraint menjadi topik hangat pasca Putusan Mahkamah Konstitusi Nomor 46/PUU-XIV/2016 yang menolak permohonan perluasan makna dari Pasal 284, Pasal 285, dan Pasal 292 Kitab Undang-Undang Hukum Pidana (KUHP). Baik judicial activism maupun judicial restraint sejatinya merupakan dua terma yang lahir dari tradisi hukum Amerika Serikat. Kedua terma tersebut secara umum melukiskan perbedaan pandangan para hakim dan ilmuwan hukum mengenai persepsi mereka terhadap hukum dan fungsi hakim di dalam bangunan ketatanegaraan yang demokratis.

Aharon Barak dalam bukunya Judge in Democracy mencoba menjelaskan makna judicial activism. Menurutnya, judicial activism merupakan sebuah 'judicial discretion' yang lahir akibat kompleksitas permasalahan yang harus diselesaikan oleh pengadilan tanpa adanya hukum (dalam arti formal) yang memadai. ${ }^{1}$ Manifestasi makna 'diskresi' dalam pendapat Aharon Barak tersebut umumnya dilakukan dalam bentuk perluasan makna dari norma hukum, perubahan makna dari norma konstitusi, penambahan norma baru, hingga putusan yang bersifat 'ultra vires'. Mengutip pendapat Chief Justice Lord Hewart: "It ... is of fundamental importance that justice should not only be done, but should manifestly and undoubtedly be seen to be done", ${ }^{2}$ judicial activism menghendaki pengadilan untuk memastikan keadilan benar-benar dapat digapai setiap warga negara semudah mereka membuka pintu rumahnya sendiri. Pandangan ini menolak gagasan tradisional tentang fungsi kekuasaan kehakiman yang sebatas hanya menafsirkan hukum yang dianggap seringkali tidak menyelesaikan masalah. Penolakan terhadap gagasan tradisional yang konservatif mengenai fungsi pengadilan ini menjadikan hakim dengan pandangan demikian disebut sebagai 'activist judge' atau hakim liberal. ${ }^{3}$ Dalam sejarah panjang Supreme Court Amerika Serikat, Chief Justice Earl Warren merupakan salah satu hakim yang diberi predikat sebagai 'activist judge' yang paling banyak melahirkan putusan bernuansa judicial activism. Salah satu satu putusannya yang kontroversial terdapat di dalam perkara Brown v. Board of Education Tahun 1954 yang menghapus kebijakan segregasi rasial pada dunia pendidikan di Amerika. ${ }^{4}$

Pandangan judicial activism mengenai fungsi pengadilan yang aktif merespon berbagai permasalahan hukum dan sosial, dianggap dapat menjadikan pengadilan

Aharon Barak, Judge in Democracy, Oxford and Princeton: Princeton University Press, 2006, hlm. 4.

Arpita Saha, "Judicial Activism in India: a Necessary Evil", http://ssrn.com/abstract=1156979.

Thomas M Keck, The Most Activist Supreme Court in History: The Road To Modern Judicial Conservatism, Chicago: The University of Chicago Press, 2004, hlm. 224.

$4 \quad$ Ibid., hlm. 38. 
sebagai institusi yang 'hiperaktif' dan eksesif. ${ }^{5}$ Para pengkritik judicial activism di Amerika mengkhawatirkan kondisi ini mencederai prinsip dasar bernegara, yakni demokrasi dan prinsip pemisahan kekuasaan. Ran Hirschl dalam Constitutional Courts vs Religious Fundamentalism: Three Middle Eastern Tales mengatakan bahwa kritik mengenai eksistensi judicial activism dan dampak buruknya merupakan sebuah pemahaman yang keliru. Dalam bantahannya, Hirschl mengatakan bahwa pembentukan pengadilan (terutama pengadilan konstitusional) tidak dapat dipisahkan dari latar belakang kenyataan sosial, budaya, politik, dan ekonomi yang terbentuk dari tatanan sistem politik tertentu; sehingga pengadilan tidak mungkin beroperasi pada dimensi yang vakum akan politik dan ideologi. ${ }^{6}$ Bagi Hirschl, pengadilan harus menjadi bagian integral untuk dapat memanifestasikan gagasan dan value politik serta ideologi yang melatar belakangi pembentukannya. Hirschl juga menolak anggapan bahwa judicial activism mencerminkan bentuk ajaran juristokrasi yang akan mencederai prinsip pemisahan kekuasaan. Bagi Hirschl, selama pengadilan tidak memiliki 'enforcement power', maka sebuah negara belum sahih menyandang predikat sebagai negara juristokrat. ${ }^{7}$

Dari perspektif ilmu politik, kehadiran judicial activism memunculkan keuntungan tersendiri bagi para aktor politik. Judicial activism membuka jalan bagi institusi politik dan aktor politik di belakangnya untuk mengalihkan penentuan kebijakan publik yang sensitif kepada pengadilan. Pengalihan ini disinyalir untuk melindungi kepentingan elektoral para elit politik yang mungkin akan terdampak akibat kebijakan publik yang akan diambil. Hirschl menyebut fenomena ini sebagai 'manuver hegemony'. ${ }^{8}$ Namun pada titik ini Hirschl tidak menjelaskan dampak manuver hegemony terhadap pengadilan, padahal manuver hegemony memiliki risiko menjadikan pengadilan sebagai objek 'politiking'.

Di sisi lain, pemahaman judicial restraint muncul dari persepsi bahwa ajaran pemisahan kekuasaan merupakan pencapaian tertinggi dari teori hukum ketatanegaraan. Pandangan ini menolak untuk mendudukan pengadilan sebagai lembaga utama (primary custodian) di dalam sistem politik. ${ }^{9}$ Judicial restraint menghendaki penentuan berbagai kebijakan publik yang akan menentukan kesejahteraan rakyat (social welfare) dilakukan melalui prosedur politik yang kompromistis di dalam institusi politik. Pandangan ini memiliki kedekatan dengan pendekatan prosedural habermasian untuk mencari titik keseimbangan dari berbagai kepentingan, aspirasi, dan nilai yang bersifat intersubjektif. ${ }^{10}$ Dengan kata

5 Ran Hirschl, "Constitutional Court vs. Religious Fundamentalism: Three Middle Eastern Tale”, Public Law and Legal Theory Research Paper No. 04-08, http://ssrn.com /abstract=557601, hlm. 38.

$6 \quad$ Ibid.

$7 \quad$ Ibid.

8 Indra Perwira, "Refleksi Fenomena Judicialization of Politics Pada Politik Hukum Pembentukan Mahkamah Konstitusi dan Putusan Mahkamah Konstitusi", Jurnal Konstitusi, Vol. 13, No. 1, Maret 2016, hlm. 29.

9 Wicaksana Dramanda, "Menggagas Penerapan Judicial Restraint Di Mahkamah Konstitusi", Jurnal Konstitusi, Vol. 11, No. 4, Desember 2014, hlm. 620.

10 Juliano Zaiden Benvindo, On The Limits of Constitutional Adjudication: Deconstructing Balancing Judicial Activism, New York: Springer, 2010, hlm. 140. 
lain, pendekatan judicial restraint memandang bahwa deliberasi publik pada forum dan institusi politik merupakan cara yang lebih demokratis dalam merumuskan kebijakan publik.

Raoul Berger dan Robert Bork mencoba memberikan identitas judicial restraint dengan lebih tegas. Menurut mereka, judicial restraint merupakan bentuk penafsiran hukum yang mengedepankan proses rekonfirmasi pada fakta-fakta sejarah yang melatarbelakangi pembentukan konstitusi. Pandangan ini mengasumsikan bahwa konstitusi sebagai dokumen hukum harus netral dari preferensi pribadi hakim dan harus lebih setia pada teks dan konteks ketika konstitusi dibentuk. Pendekatan ini dikenal sebagai pendekatan 'originalism'. ${ }^{11}$ Kesetiaan para pendukung originalism pada teks dan konteks masa lalu ini mengakibatkan stigma konservatif melekat pada para pendukungnya. Meskipun cenderung lebih kaku, pendekatan originalism lebih mencerminkan prinsip kehati-hatian pengadilan dalam memutus perkara. Justice Antonin Scalia merupakan salah satu hakim yang dikenal sebagai pendukung judicial restraint melalui cara pandangnya yang begitu konservatif. Scalia bahkan dinobatkan sebagai 'bapak textualism', sebuah metode penafsiran yang mengedepankan makna tekstual. Menurut Scalia, proposisi norma yang berisi kata-kata memiliki keterbatasan arti, dan tugas hakim hanya menentukan mana arti yang tepat secara hukum. ${ }^{12}$

Berbagai doktrin mengenai judicial restraint, umumnya merupakan doktrin yang memberikan pembatasan terhadap kewenangan pengadilan. Dari berbagai doktrin tersebut, setidaknya terdapat tiga bentuk pembatasan, yakni Pertama, pembatasan yang dilakukan dengan memberikan limitasi terhadap kewenangan atau yurisdiksi pengadilan melalui norma-norma di dalam konstitusi (constitutional limitation). Kedua, pembatasan yang dilakukan dengan menerapkan kebijakan internal pengadilan yang bersumber dari kehendak pengadilan untuk melakukan pengekangan diri (policy limitation/self-restraint). Ketiga, pembatasan yang dilakukan berdasarkan doktrin-doktrin tertentu (doctrine limitation). ${ }^{13}$

Pada dasarnya, judicial activism dan judicial restraint muncul dari kesadaran yang sama bahwa terdapat sebuah keniscayaan di dalam tatanan masyarakat dan interaksi sosial di dalamnya, yakni 'perubahan'. Keniscayaan tersebut menghasilkan sebuah fenomena kesenjangan antara kebutuhan sosial dengan hukum sebagai instrumen yang menjamin interaksi sosial terjadi dengan cara yang tertib dan teratur. ${ }^{14}$ Namun, pendekatan untuk menyelesaikan kesenjangan tersebut menjadi garis demarkasi antara judicial activism dengan judicial restraint. Meskipun judicial activism dan judicial restraint berpijak pada pondasi yang sama, yakni demokrasi,

11 Jerold Waltman, Principled Judicial Restraint: A Case Against Activism, New York: Palgrave Mcmillan, 2015, hlm. 40.

12 Antonin Scalia (et.al), A Matter of Interpretation: Federal Courts and the Law, Princeton and Chicester: Princeton University Press, 1997, hlm. Ix.

3 Wicaksana Dramanda, Op. cit., hlm. 621.

14 Aharon Barak, Op.cit., hlm. 3. 
para hakim yang mendukung pandangan judicial activism cenderung menganggap pengadilan sebagai subjek yang dominan di dalam relasi antar institusi pada level suprastruktur politik. Di sisi lain, judicial restraint dan para pendukungnya beranggapan bahwa pengadilan bukanlah 'pemeran utama' di dalam relasi tersebut dan menghendaki peran dominan tetap berada pada institusi yang mencerminkan representasi rakyat.

Meskipun begitu, sebagaimana hakekat dari sebuah putusan pengadilan, judicial activism maupun judicial restraint tidak dapat dijadikan dasar untuk melegitimasi sebuah putusan. Putusan pengadilan mendapatkan legitimasinya hanya ketika pengadilan memutus berdasarkan hukum. ${ }^{15}$ Makna memutus berdasarkan hukum diartikan oleh Mark Elliot sebagai sebuah putusan yang dihasilkan dengan caracara yang sejalan dengan prinsip-prinsip umum, baik hukum maupun politik, yang mendasari terbentuknya konstitusi. ${ }^{16}$ Mengutip pendapat Sir Edward Coke beberapa abad yang lalu: "Reason is the life of the law", ${ }^{17}$ artinya legitimasi putusan pengadilan hanya dapat dilihat atau dinilai melalui alasan atau pertimbangan-pertimbangan yang mendasari mengapa sebuah putusan dijatuhkan. Oleh karena itu, alasan (reason) ini pulalah yang harus menjadi dasar mengapa sebuah penyelesaian perkara harus didekati dengan pendekatan judicial activism atau judicial restraint. Penggunaan reason sebagai basis penentuan pendekatan yang akan digunakan, sejatinya mencerminkan sikap pengadilan yang lebih pragmatis dalam menghadapi perkara.

Meskipun dapat digunakan secara pragmatis, judicial activism dan judicial restraint tetap perlu didudukan secara tepat dalam konteks pelaksanaan fungsi pengadilan. Kapan judicial activism maupun judicial restraint dapat 'mewarnai' putusan pengadilan memang tidak dapat direncanakan bagai merumuskan fungsifungsi algoritma. Namun, dalam konteks mencari keseimbangan diantara judicial activism dan judicial restraint, perlu untuk menentukan 'pemicu minimum' yang sah secara hukum. Dalam hal ini, menarik untuk melihat pola penggunaan judicial activism di Amerika. Judicial activism selalu dikaitkan dengan beberapa putusan landmark seperti Brown v Board of Education tahun 1954 maupun Roe v Wade tahun 1973. Dalam perkara Brown v Board of Education, judicial activism di dalam putusan pengadilan mengambil bentuk berupa pembatalan precedent atau putusan sebelumnya yang menjadi dasar segregasi rasial di Amerika melalui doktrin separate but equal. ${ }^{18}$ Fakta sejarah kemudian menunjukan bahwa putusan ini telah memicu perubahan paradigmatik pada dimensi kebijakan publik Amerika terkait hak-hak masyarakat kulit hitam. Pasca putusan ini, kebijakan publik Amerika cenderung mengarah pada desegregasi dan pemberian kebijakan affirmative action

Bagir Manan, Menegakan Hukum Suatu Pencarian, Jakarta: Asosiasi Advokat Indonesia, 2009, hlm. 171.

Mark Elliot, The Constitutional Foundation of Judicial Review, Oxford: Hart Publishing, 2001, hlm. v.

Daniel A Farber, Suzanna Sherry, Judgement Calls: Principle and Politics in Constitutional Law, Oxford: Oxford University Press, 2009, hlm. 43.

18 Ibid., hlm. 106. 
bagi masyarakat kulit hitam. Putusan pengadilan dalam perkara Brown $v$ Board of Education dapat dibaca sebagai sebuah upaya melindungi kebebasan dan persamaan bagi masyarakat kulit hitam yang sejatinya telah dijamin di dalam konstitusi. Begitu pula yang terjadi pada perkara Roe $v$ Wade Tahun 1973. Judicial activism mengambil bentuk berupa pembentukan norma baru yang menjamin kebebasan bagi wanita atas fungsi reproduksinya. ${ }^{19}$ Dalam putusannya, pengadilan menyatakan bahwa praktik aborsi dapat dibenarkan pada trimester pertama masa kehamilan dengan alasan-alasan tertentu. Hal ini dapat dibaca sebagai bentuk pemenuhan jaminan atas hak diri pribadi (privacy rights) sebagaimana telah dijamin di dalam konstitusi. ${ }^{20}$

Pola di atas mencerminkan bahwa judicial activism selalu dilakukan dalam rangka menjamin kebebasan warga negara sebagaimana dilindungi oleh konstitusi dan bukan sebaliknya. Artinya, proposisi 'menjamin kebebasan' dapat menjadi pemicu bagi pengadilan untuk dapat bersikap aktif dalam memutus perkara dengan pendekatan judicial activism. Proposisi 'menjamin kebebasan' juga dapat menjadi sumber legitimasi dan penerimaan publik terhadap judicial activism mengingat kebebasan adalah hakikat dasar manusia yang dijamin oleh konstitusi. ${ }^{21}$

Meskipun begitu, berbagai kritik terhadap judicial activism (termasuk diantaranya kritik yang didasarkan pada pemahaman judicial restraint) tidak dapat dihiraukan. Oleh karena itu, dalam kerangka demokrasi, judicial activism harus dibaca sebagai sesuatu yang berbahaya namun dibutuhkan (necessary evil). Sebagai sebuah necessary evil, maka penggunaan pendekatan judicial activism harus dilakukan dengan sangat selektif. Sementara itu, judicial restraint, karena karakternya yang cenderung untuk menarik diri dan melimpahkan penyelesaian perkara pada cabang kekuasaan yang lain, harus dibaca sebagai sebuah kehati-hatian pengadilan guna menjamin keberlangsungan demokrasi dan pemisahan kekuasaan.

Artikel terpilih dalam Jurnal Padjadjaran edisi kali ini membahas beragam isu dari mulai hukum pidana, hukum HAM, cyber law, hukum internasional, dan hukum merek. Artikel kehormatan ditulis oleh Prof. Agus Sardjono mengenai simfonisasi hukum kekayaan intelektual dalam pemajuan kebudayaan. Prof. Tarsisius Murwadji dan Achmad Hagi Robby membuka wacana dengan membahas mengenai edukasi dan penyehatan koperasi melalui linkage program perbankan. Widati Wulandari dan Tristam P. Moellono membahas problematika pengertian Aanslag-Aanslag tot en feit: perbandingan makar dalam KUHP, WvSNI dan Sr. Inna Junaenah dan Lailani Sungkar membahas mengenai model panduan kriteria desa peduli hak asasi manusia dalam konteks Jawa Barat. Nia Kurniati membahas perlindungan hukum merek terhadap produk Teri Biru Seira dan Kerupuk Ikan Tanimbar sebagai industri kreatif masyarakat di Kota Saumlaki. Rocky Marbun membahas mengenai diskursus perumusan ideologi sebagai perbuatan pidana dalam rangka Rancangan Kitab Undang-Undang Hukum Pidana 2015. Muh. Insa Ansari membahas penugasan pemerintah pada BUMN

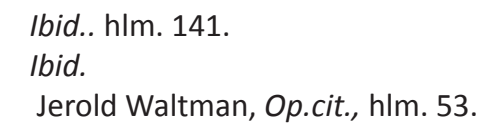


sektor ketenagalistrikan dalam perspektif hukum korporasi. Budi Hermawan Bangun mengupas Peran ASEAN dalam melakukan penanganan pengungsi Rohingya. Wahyu Hardiangsih, Hari Purwadi, dan Emmy Latifah membahas ketiadaan pengaturan kuota ekspor hiu tikus (Alopias Ssp.) di Indonesia dan Akibat-Akibat Hukumnya. Di bagian akhir, Darmaini Roza dan Laurensius membahas peran badan permusyawaratan desa di dalam pembangunan desa dan pengawasan keuangan desa. Rubrik book review kali ini ditulis oleh Chloryne Tri Isana Dewi atas buku berjudul Islam and Human Rights, Tradition, and Politics yang disusun oleh Ann Elizabeth Mayer. Untuk Rubrik Khazanah pada edisi ini akan membahas pemikiran filsuf Ludwig Feuerbach.

Selamat membaca! 